\title{
High genetic diversity among Pseudomonas aeruginosa and Acinetobacter spp. isolated in a public hospital in Brazil
}

\author{
Vera Lúcia Dias Siqueira ${ }^{1, *}$, Rosilene Fressatti Cardoso², Rubia Andreia Falleiros de Pádua ${ }^{2}$, \\ Katiany Rizzieri Caleffi-Ferracioli ${ }^{2}$, Cesar Helbel $^{3}$, Adolfo Carlos Barreto Santos ${ }^{4}$, \\ Elisabeth Eyko Aoki ${ }^{3}$, Celso Vataru Nakamura ${ }^{1}$
}

\author{
${ }^{1}$ Postgraduate Program in Pharmaceutical Science, ${ }^{2}$ Department of Clinical Analysis and Biomedicine, ${ }^{3}$ University Hospital \\ of Maringá, State University of Maringá, ${ }^{4}$ Laboratory of Mycobacteriology, Department of Biological Science, School of \\ Pharmaceutical Science, Paulista State University
}

\begin{abstract}
In Brazil and other regions of the world, Pseudomonas aeruginosa and Acinetobacter spp. have emerged as important agents of nosocomial infection and are commonly involved in outbreaks. The main objective of the present study was to evaluate the genetic relationship among $P$. aeruginosa and Acinetobacter spp. isolated from patients in a public university hospital in northwestern Paraná, Brazil, and report their antimicrobial resistance profile. A total of 75 P. aeruginosa and 94 Acinetobacter spp. isolates were phenotypically identified and tested for antibiotic susceptibility using automated methodology. Polymyxin B was tested by disk diffusion for $P$. aeruginosa. Metallo- $\beta$-lactamase (MBL) was detected using a disk approximation test. Genotyping was performed using enterobacterial repetitive intergenic consensus polymerase chain reaction (ERIC-PCR). Approximately 55\% of the $P$. aeruginosa isolates and $92 \%$ of the Acinetobacter spp. isolates were multiresistant, but none were MBL-producers. ERIC-PCR revealed the presence of small clusters of carbapenem-resistant Acinetobacter spp., most likely OXA-type carbapenemase producers. Furthermore, high genetic diversity in P. aeruginosa and Acinetobacter spp. clinical isolates was observed, suggesting that cross-transmission is not very frequent in the studied hospital.
\end{abstract}

Uniterms: Pseudomonas aeruginosa/antimicrobial resistance profile. Pseudomonas aeruginosa/genetic study. Acinetobacter spp./antimicrobial resistance profile. Acinetobacter spp./genetic study. Antimicrobial resistance. Bacterial typing.

No Brasil, bem como em outras regiões do mundo, Pseudomonas aeruginosa e Acinetobacter spp. surgiram como importantes agentes de infecção nosocomial e são comumente envolvidos em surtos. O objetivo principal deste estudo foi descrever a relação genética de P. aeruginosa e Acinetobacter spp. isoladas de pacientes internados em hospital universitário público do noroeste do Paraná - Brasil e reportar o perfil de resistência dessas bactérias. Um total de 75 P. aeruginosa e 94 Acinetobacter spp. isolados foi fenotipicamente identificado e testado para a suscetibilidade aos antibióticos por metodologia automatizada. A polimixina B foi testada por difusão em disco para P. aeruginosa. Metalo- $\beta$-lactamase (MBL) foi detectada por disco-aproximação. Análise genotípica foi realizada por enterobacterial repetitive intergenic consensus polymerase chain reaction (ERIC-PCR). Aproximadamente $55 \%$ dos isolados de $P$. aeruginosa e $92 \%$ de Acinetobacter spp. isolados foram multirresistentes, mas nenhum foi produtor de MBL. Os resultados de ERIC-PCR revelaram pequenos grupamentos de Acinetobacter spp. resistentes aos carbapenêmicos, provavelmente pela produção de carbapenemases do tipo OXA. Além disso, alta diversidade genética entre os isolados de P. aeruginosa e Acinetobacter spp. foi observada, sugerindo que a transmissão cruzada destas espécies bacterianas não é muito frequente em nosso hospital.

Unitermos: Pseudomonas aeruginosa/perfil de resistência. Pseudomonas aeruginosa/estudo genético. Acinetobacter spp./perfil de resistência. Acinetobacter spp./estudo genético. Resistência antimicrobiana. Tipagem bacteriana.

\footnotetext{
*Correspondence: Laboratório de Bacteriologia Médica. Departamento de Análises Clínicas e Biomedicina, Universidade Estadual de Maringá. Av. Colombo, 5790, Bloco T-20, sala 202, 87020-900 - Maringá - Paraná, Brasil. Telefone: 5544 3011-5376. E-mail: vldsiqueira@uem.br
} 


\section{INTRODUCTION}

Pseudomonas aeruginosa and Acinetobacter spp. have been the cause of nosocomial outbreaks worldwide (Cortes et al., 2009; Hosoglu et al., 2011), including in Brazil (Brito et al., 2003; Prates et al., 2011), where multidrug resistance is common among these isolates (Rossi, 2011). Carbapenems often represent the only effective treatment. However, carbapenem-resistant isolates have frequently been detected, leading clinicians to resume the use of older classes of antibiotics, such as polymyxins (Giamarellou, 2010). The production of carbapenemase enzymes has been an important mechanism of resistance in these bacteria. Metallo- $\beta$-lactamases (MBLs), enzymes able to hydrolyze all $\beta$-lactam antibiotics with the exception of monobactams, are particularly common in $P$. aeruginosa, and the genes that encode them are carried by highly mobile elements that play an important role in hospital environments (Cornaglia, Giamarellou, Rossolini, 2011)

Enterobacterial repetitive intergenic consensuspolymerase chain reaction (ERIC-PCR) has shown good applicability in typing $A$. baumannii and $P$. aeruginosa (Presterl et al., 1997; Syrmis et al., 2004; Kidd et al., 2011). Although some studies have used ERIC-PCR to epidemiologically study $P$. aeruginosa and Acinetobacter spp. nosocomial isolates in Brazil (Costa et al., 2006; Saalfeld et al., 2009; Stehling, Leite, Silveira, 2010; Ferreira et al., 2011; Viana et al., 2011), the specific epidemiology of these microorganisms remains unknown.

The main objective of the present study was to describe the genetic relationship among $P$. aeruginosa and Acinetobacter spp. clinical isolates using ERIC-PCR and report their resistance profiles against antimicrobial agents that are routinely used in a public university hospital in northwestern Paraná, Brazil.

\section{MATERIAL AND METHODS}

Seventy-five $P$. aeruginosa and 94 Acinetobacter spp. isolates from various clinical specimens from patients admitted to a public hospital in northwestern Paraná, Brazil, between January 2007 and July 2009 were studied. Only one isolate from each patient was selected and stored at $-80^{\circ} \mathrm{C}$ in the Laboratory of Medical Bacteriology, Department of Clinical Analysis and Biomedicine, State University of Maringá. No personal data were retrieved from the patients, so privacy could be assured and legal transgressions concerning human research could be avoided (Resolution 196/96 Brazil National Health Council, Health Ministry). The present study was approved by the Regulatory Commission of Academic Activities and Voluntary Services of the studied hospital.

Phenotypic identification and antimicrobial susceptibility testing (AST) were performed using an AUTOSCAN-4 automated system (Siemens Microscan, Deerfield, IL, USA), with the exception of polymyxin B for $P$. aeruginosa, which was tested by disk diffusion. The data were interpreted according to the criteria of the Clinical and Laboratory Standards Institute (CLSI; 2007-2009).

Ceftazidime-resistant $P$. aeruginosa and Acinetobacter spp. isolates were evaluated for the presence of MBL using the disk-approximation test, 2-mercaptopropionic acid (2-MPA; Acros, Bridgewater, NJ, USA), and ethylenediaminetetraacetic acid (EDTA; Invitrogen, Carlsbad, CA, USA; Arakawa et al. 2000). IMP-1-producing Acinetobacter baumannii (A-3227) and P. aeruginosa ATCC 27853 were used as positive and negative controls, respectively.

Genomic DNA of $P$. aeruginosa and Acinetobacter spp. isolates was extracted from overnight bacterial growth on Mueller-Hinton agar (Difco, Becton Dickinson, Sparks, MD, USA; Swanenburg et al., 1998). The PCRs were performed using primers ERIC1R (5'-ATGTAAGCTCCTGGGGATTCAC-3') and ERIC2 (5'-AAGTAAGTGACTGGGGTGAGCG-3') as described by Szczuka and Kaznowski (2004). The gels were stained with ethidium bromide, and the spectral band analysis on agarose gels was performed using BioNumerics software (version 4.45, Applied Maths, Sint-Martens-Latem, Belgium). The Dendrogram was constructed using the Dice coefficient, and the phylogenetic distance was determined using the Unweighted Pair Group Method with Arithmetic Mean algorithm (Sneath and Sokal, 1973). Isolates with $\geq 95 \%$ similarity were considered closely related.

\section{RESULTS}

The studied institution is a small-size public hospital with three intensive care units (ICUs): adult, pediatric, and neonatal. P. aeruginosa and Acinetobacter spp. were isolated more frequently in male patients $(62.7 \%$ and $59.6 \%$, respectively), especially in patients older than 60 years (54.7\% and 39.4\%, respectively) and in ICUs (41.4\% and $71.3 \%$, respectively). $P$. aeruginosa isolates were detected at a higher frequency in urine samples, whereas Acinetobacter spp. isolates were mainly recovered from tracheal aspirate.

The resistance rate in $P$. aeruginosa isolates was less than $30 \%$ for most of the $\beta$-lactam antibiotics, and $54.6 \%$ were multiresistant (i.e., resistant to three or more antimicrobial classes; Magiorakos et al., 2012). All of the isolates were polymyxin B-susceptible. For Acinetobacter 
spp. isolates, the $\beta$-lactam resistance rate was greater than $90 \%$ to cephalosporins and greater than $50 \%$ to the tested carbapenems (Table I). Multiresistance was observed in $91.5 \%$. None of the P. aeruginosa $(n=39)$ and Acinetobacter spp. $(n=88)$ isolates with total or intermediate resistance to ceftazidime were positive for MBL.

TABLE I - Resistance profiles of Pseudomonas aeruginosa and Acinetobacter spp. isolates from inpatients in a public hospital in northwestern Paraná, Brazil

\begin{tabular}{lcc}
\hline \multirow{2}{*}{ Antimicrobial agent } & \multicolumn{2}{c}{ Resistant isolates (\%) } \\
\cline { 2 - 3 } & $\begin{array}{c}\text { P. aeruginosa } \\
(n=75)\end{array}$ & $\begin{array}{c}\text { Acinetobacter } \text { spp. } \\
(n=94)\end{array}$ \\
\hline Aztreonam & $13(29.3)^{\mathrm{a}}$ & $\mathrm{NT}$ \\
Amikacin & $30(40.0)$ & $53(56.4)$ \\
Ampicillin/Sulbactam & $\mathrm{NT}$ & $21(27.6)^{\mathrm{b}}$ \\
Cefepime & $22(29.3)$ & $87(92.5)$ \\
Ceftazidime & $21(28.0)$ & $85(90.4)$ \\
Ciprofloxacin & $37(49.3)$ & $88(93.6)$ \\
Gentamicin & $33(44.0)$ & $70(74.5)$ \\
Imipenem & $19(25.4)$ & $52(54.8)$ \\
Meropenem & $19(25.4)$ & $53(56.4)$ \\
Piperacillin/Tazobactam & $10(13.3)$ & $\mathrm{NT}$ \\
Polymyxin B & $0.0(0.0)$ & $\mathrm{NT}$ \\
Trimethoprim/ & $\mathrm{NT}$ & $88(93.6)$ \\
Sulfamethoxazole & &
\end{tabular}

NT, not tested; ${ }^{\mathrm{a}}$ Tested isolates $=46 ;{ }^{\mathrm{b}}$ Tested isolates $=76$.

The ERIC-PCR applied to P. aeruginosa and Acinetobacter $\mathrm{spp}$. clinical isolates showed a banding pattern with sizes that rang, from approximately $120 \mathrm{pb}$ to $1200 \mathrm{pb}$ and $120 \mathrm{pb}$ and $1900 \mathrm{pb}$, respectively.

Considering a Dice correlation coefficient $\geq 0.95$, 72 ERIC-PCR patterns were obtained in 75 P. aeruginosa clinical isolates. Seventy isolates (93.3\%) were orphans, and the remaining five $(6.7 \%)$ were included in two clusters comprising two (cluster A) and three (cluster B) isolates (Figure 1).

Two isolates that belonged to cluster A showed identical antimicrobial resistance profiles and were isolated from patients in different clinical units within a time interval of approximately 2 months. Isolates that belonged to cluster B, two with $100 \%$ similarity, had equal resistance profiles and were isolated from patients in an adult ICU within a time interval of only 4 days. The third isolate that belonged to cluster $\mathrm{B}$, despite having the same resistance profile, was isolated 13 days later in a patient admitted to the pediatric unit (Table II).

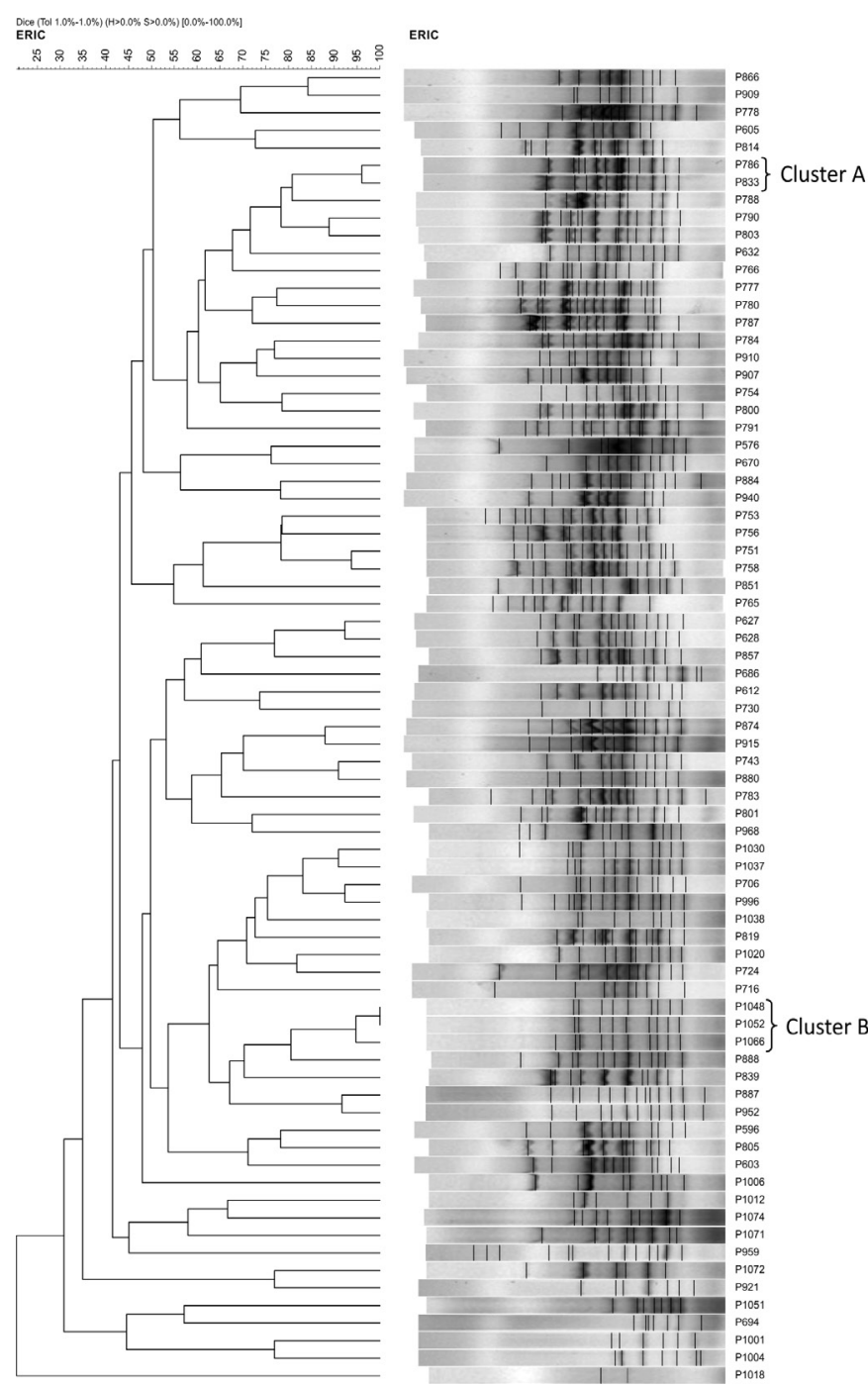

FIGURE 1. Dendrogram and DNA-banding profiles that represent the genetic relationship among Pseudomonas aeruginosa isolated from clinical specimens of inpatients in a public hospital in northwestern Paraná, Brazil.

A total of 70 Acinetobacter spp. isolates (74.5\%) showed orphan ERIC-PCR patterns, and the remaining 24 $(25.5 \%)$ were included in 10 clusters (C-L) comprising two isolates each, with the exception of clusters $\mathrm{D}$ and $\mathrm{H}$ with three isolates each (Figure 2).

The several small clusters found in Acinetobacter spp. were generally detected in the same unit or units with displacement of patients, such as the adult ICU and medical clinic. Exceptions were observed in clusters D and J, which were composed of isolates from the adult and pediatric ICUs. Acinetobacter clusters included isolates with similar resistance profiles, with some differences related to aminoglycosides and carbapenems. Notably, $60 \%$ of the small clusters were carbapenems-resistant Acinetobacter spp. (Table II). 
TABLE II - Demographics and phenotypic and genotypic features of Pseudomonas aeruginosa and Acinetobacter spp. isolates with similarity $\geq 95 \%$

\begin{tabular}{|c|c|c|c|c|c|}
\hline Cluster & Microorganism (isolate) & Clinical Specimens & Date of Isolation & Hospital Ward & $\begin{array}{c}\text { Antimicrobial Resistance } \\
\text { Pattern }\end{array}$ \\
\hline A & P. aeruginosa (786) & Urine & 4 Mar 2008 & Pediatrics & $\begin{array}{l}\text { Susceptible to all tested } \\
\text { antimicrobials }\end{array}$ \\
\hline A & P. aeruginosa (833) & Tracheal aspirate & 12 May 2008 & Adult ICU & $\begin{array}{l}\text { Susceptible to all tested } \\
\text { antimicrobials }\end{array}$ \\
\hline B & P. aeruginosa (1048) & Tracheal aspirate & 12 Jun 2009 & Adult ICU & Cip; Azt; Cef; Cfz \\
\hline B & P. aeruginosa (1052) & Blood & 8 Jun 2009 & Adult ICU & Cip; Azt; Cef; Cfz \\
\hline B & P. aeruginosa (1066) & Urine & 25 Jun 2009 & Medical clinic & Cip; Azt; Cef; Cfz \\
\hline $\mathrm{C}$ & Acinetobacter spp. (885) & Urine & 13 Jul 2008 & Medical clinic & Amp/Sul; Cip; Sut; Cef; Cfz \\
\hline $\mathrm{C}$ & Acinetobacter spp. (893) & Tracheal aspirate & 14 Aug 2008 & Adult ICU & $\begin{array}{c}\text { Amp/Sul; Cip; Sut; Cef; Cfz; } \\
\text { Gen; Ami }\end{array}$ \\
\hline $\mathrm{D}$ & Acinetobacter spp. (1033) & Tracheal aspirate & 14 May 2009 & Pediatric ICU & $\begin{array}{l}\text { Amp/Sul; Cip; Sut; Cef; Cfz; } \\
\text { Gen; Ami; Imp; Mer }\end{array}$ \\
\hline $\mathrm{D}$ & Acinetobacter spp. (1067) & Tracheal aspirate & 24 Jun 2009 & Adult ICU & $\begin{array}{l}\text { Amp/Sul; Cip; Sut; Cef; Cfz; } \\
\text { Gen; Ami; Imp; Mer }\end{array}$ \\
\hline $\mathrm{D}$ & Acinetobacter spp. (1043) & Tracheal aspirate & 25 May 2009 & Adult ICU & $\begin{array}{l}\text { Amp/Sul; Cip; Sut; Cef; Cfz; } \\
\text { Gen; Ami; Imp; Mer }\end{array}$ \\
\hline $\mathrm{E}$ & Acinetobacter spp. (1002) & Urine & 4 Mar 2009 & Adult ICU & $\begin{array}{l}\text { Amp/Sul; Cip; Sut; Cef; Cfz; } \\
\text { Gen; Ami; Imp; Mer }\end{array}$ \\
\hline $\mathrm{E}$ & Acinetobacter spp. (1024) & Blood & 23 Mar 2009 & Medical clinic & $\begin{array}{l}\text { Amp/Sul; Cip; Sut; Cef; Cfz; } \\
\text { Gen; Ami; Imp; Mer }\end{array}$ \\
\hline $\mathrm{F}$ & Acinetobacter spp. (900) & Tracheal aspirate & 20 Aug 2008 & Adult ICU & Cip; Sut; Cef; Cfz; Gen; Ami \\
\hline $\mathrm{F}$ & Acinetobacter spp. (918) & Tracheal aspirate & 24 Sep 2008 & Adult ICU & Cip; Sut; Cef; Cfz; Gen; Ami \\
\hline G & Acinetobacter spp. (573) & Urine & 17 Feb 2007 & Adult ICU & $\begin{array}{l}\text { Amp/Sul; Cip; Sut; Cef; Cfz; } \\
\text { Gen; Ami; Imp; Mer }\end{array}$ \\
\hline G & Acinetobacter spp. (585) & Blood & 15 Mar 2007 & Adult ICU & $\begin{array}{c}\text { Amp/Sul; Cip; Sut; Cef; Cfz; } \\
\text { Gen; Imp; Mer }\end{array}$ \\
\hline $\mathrm{H}$ & Acinetobacter spp. (559) & Surgical wound & 29 Jan 2007 & Adult ICU & $\begin{array}{l}\text { Amp/Sul; Cip; Sut; Cef; Cfz; } \\
\text { Gen; Ami; Imp; Mer }\end{array}$ \\
\hline $\mathrm{H}$ & Acinetobacter spp. (564) & Tracheal aspirate & 29 Jan 2007 & Adult ICU & $\begin{array}{l}\text { Amp/Sul; Cip; Sut; Cef; Cfz; } \\
\text { Gen; Ami; Imp; Mer }\end{array}$ \\
\hline $\mathrm{H}$ & Acinetobacter spp.(548) & Tracheal aspirate & 3 Jan 2007 & Adult ICU & $\begin{array}{l}\text { Amp/Sul; Cip; Sut; Cef; Cfz; } \\
\text { Gen; Ami; Imp; Mer }\end{array}$ \\
\hline I & Acinetobacter spp. (611) & Tracheal aspirate & 17 Apr 2007 & Adult ICU & $\begin{array}{c}\text { Cip; Sut; Cef; Cfz; Gen; Ami; } \\
\text { Imp; Mer }\end{array}$ \\
\hline I & Acinetobacter spp. (613) & Tracheal aspirate & 26 Apr 2007 & Adult ICU & $\begin{array}{c}\text { Amp/Sul; Cip; Sut; Cef; Cfz; } \\
\text { Gen; Imp; Mer }\end{array}$ \\
\hline $\mathrm{J}$ & Acinetobacter spp. (554) & Tracheal aspirate & 16 Jan 2007 & Adult ICU & Cip; Sut; Cef; Cfz; Gen; Ami \\
\hline $\mathrm{J}$ & Acinetobacter spp. (557) & Tracheal aspirate & 4 Feb 2007 & Pediatric ICU & Cip; Sut; Cef; Cfz; Gen; Ami \\
\hline $\mathrm{K}$ & Acinetobacter spp. (566) & Tracheal aspirate & 22 Jan 2007 & Medical clinic & Cip; Sut; Cef; Cfz; Ami \\
\hline K & Acinetobacter spp. (568) & Tracheal aspirate & 15 Feb 2007 & Adult ICU & Cip; Sut; Cef; Cfz; Gen; Ami \\
\hline $\mathrm{L}$ & Acinetobacter spp. (610) & Tracheal aspirate & 17 Apr 2007 & Adult ICU & $\begin{array}{l}\text { Amp/Sul; Cip; Sut; Cef; Cfz; } \\
\text { Gen; Ami; Imp; Mer }\end{array}$ \\
\hline $\mathrm{L}$ & Acinetobacter spp. (617) & Tracheal aspirate & 11 May 2007 & Adult ICU & Cip; Sut; Cef; Cfz; Gen; Ami \\
\hline
\end{tabular}




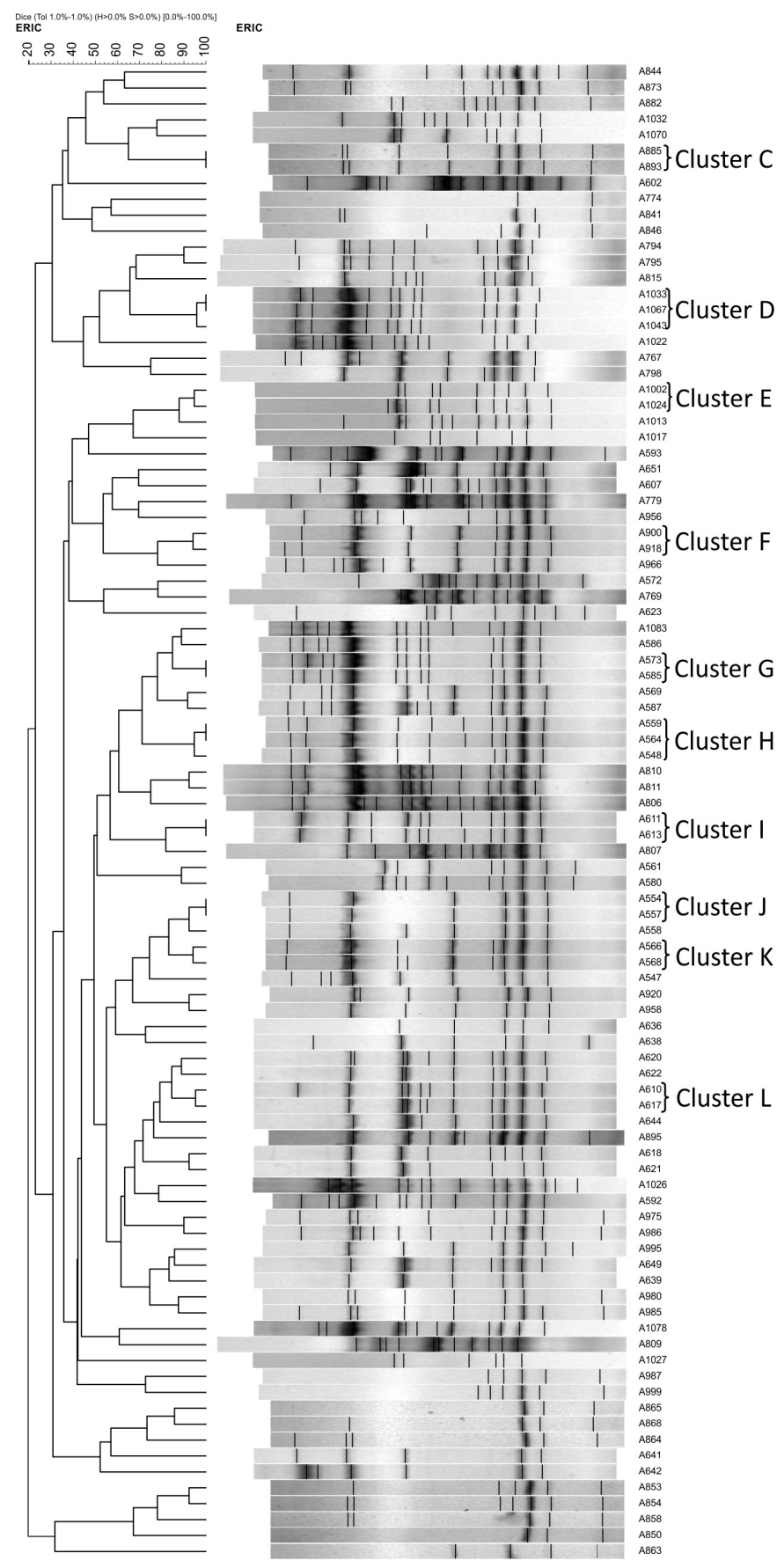

FIGURE 2. Dendrogram and DNA-banding profiles that represent the genetic relationship among Acinetobacter spp. isolated from clinical specimens of inpatients in a public hospital in northwestern Paraná, Brazil.

\section{DISCUSSION}

In the present study, the ERIC-PCR assessment and antimicrobial resistance profiles of $P$. aeruginosa and Acinetobacter spp. isolates from inpatients in a small-size teaching hospital in northwestern Paraná showed a high percentage of multiresistance and genetic diversity. Worrying rates of ceftazidime and carbapenems resistance were observed in P. aeruginosa isolates. However, they were smaller than those observed in isolates from other university hospitals in Brazil, where resistance to these antimicrobials was near or greater than $50 \%$ (Zavascki, Cruz, Goldani, 2004; Rocha et al., 2008).

In recent years, MBL production has represented an important mechanism of resistance to most $\beta$-lactam antibiotics, including carbapenems, especially in P. aeruginosa (Kunz, Brook, 2010). However, despite a resistance rate of just over $25 \%$ detected for carbapenems, none of the $P$. aeruginosa isolates tested were positive for MBL, demonstrating the probable participation of other resistance mechanisms. The isolation rates of MBL-producing $P$. aeruginosa have widely varied among Brazilian hospitals, with incidences ranging from 3.1\% (Wirth et al., 2009) to 35\% (Gonçalves et al., 2009). According to Rossi (2011), São Paulo metallo- $\beta$-lactamase (SPM) is the most prevalent MBL in Brazilian isolates. For Acinetobacter spp. isolated in the present study, the observed resistance rates of $>90 \%$ for third-generation cephalosporins and nearly $55 \%$ for carbapenems may be responsible for the difficulty treating these cases, which has been reported in other studies (Towner, 2009; Kunz, Brook, 2010). MBL was not detected in isolates from this genus, which corroborates other studies that found a low contribution of this enzyme to the increasing rates of resistance in Acinetobacter spp. (Mostachio et al., 2009; Kunz, Brook, 2010). OXA-type $\beta$-lactamases have shown an important role in carbapenem-resistant Acinetobacter spp. (Poirel, Naas, Nordmann, 2010). In Acinetobacter spp. isolates from Brazilian hospitals, carbapenem resistance is mostly related to $\beta$-lactamase OXA-23 (Gales et al., 2012). However, a recent study found a high prevalence of OXA-143 in these bacterial genera (Mostachio et al., 2012). Therefore, the small clusters of carbapenem-resistant Acinetobacter spp. isolated in this study may have been OXA-type carbapenemase producers.

Although clonal spread is commonly found in hospitals worldwide (Scott and Pitt, 2004; Cortes et al., 2009), including Brazil (Stheling, Leite, Silveira, 2010), the present study detected high genetic diversity, especially among P. aeruginosa isolates. Only two (2.7\%) of the 75 isolates showed identical ERIC-PCR patterns (100\% similarity), and five $(6.7 \%)$ had $\geq 95 \%$ similarity. However, according to the phenotypic features and demographic conditions, the cross-spread of small clusters of $P$. aeruginosa and Acinetobacter spp., including carbapenem-resistant isolates, among patients in the hospital, was evident. Importantly, however, the findings of Saalfeld et al. (2009) should be 
considered, in which high genetic similarity was found among clinical and environmental Acinetobacter spp. isolates in an adult ICU in the same hospital from January to July 2008. These authors suggested that an endemic situation existed by observing the genotypic similarity of isolates using a Dice correlation coefficient $>90 \%$.

\section{CONCLUSION}

Using ERIC-PCR, the present study found high genetic diversity among $P$. aeruginosa and Acinetobacter spp. isolates, suggesting that cross-contamination is not very frequent in the studied hospital. Because of the known applicability of ERIC-PCR, its good discriminatory power and reproducibility allowed an understanding of the epidemiology of these bacteria in the studied hospital environment.

\section{ACKNOWLEDGEMENTS}

The present research received financial support from Agência Nacional de Vigilância Sanitária (ANVISA)/PanAmerican Health Organization (PAHO).

\section{REFERENCES}

ARAKAWA, Y.; SHIBATA, N.; SHIBAYAMA, K.; KUROKAWA, H.; YAGI, T.; FUJIWARA, H.; GOTO, $\mathrm{M}$. Convenient test for screening metallo-beta-lactamaseproducing gram-negative bacteria by using thiol compounds. J. Clin. Microbiol., v.38, n.1, p.40-43, 2000.

BRITO, D.V.D.; OLIVEIRA, E.J.; DARINI, A.L.C.; ABDALLAH, V.O.S.; GONTIJO-FILHO, P.P. Nosocomial outbreaks due to Pseudomonas aeruginosa and Acinetobacter baumannii in a neonatal intensive care unit (nICU) of the Uberlândia federal university hospital. Braz. J. Microbiol., v.34, suppl.1, p.27-28, 2003.

CLINICALAND LABORATORY STANDARDS INSTITUTE. CLSI. Performance Standards for Antimicrobial Susceptibility Testing: Wayne, 2007. 177 p. (M100-S-17 Seventeenth Informational Supplement).

CLINICALAND LABORATORY STANDARDS INSTITUTE. CLSI. Performance Standards for Antimicrobial Susceptibility Testing:. Wayne, 2008. 181 p. (M100-S-18 Eighteenth Informational Supplement).
CLINICALAND LABORATORY STANDARDS INSTITUTE.

CLSI. Performance Standards for Antimicrobial Susceptibility Testing: Wayne, 2009. 149 p. (M100-S19 Nineteenth Informational Supplement).

CORTES, J.A.; CUERVO, S.I.; URDANETA, A.M.; POTDEVIN, G.; ARROYO, P.; BERMÚDEZ, D.; CORREA, A.; VILLEGAS, M.V. Identifying and controlling a multiresistant Pseudomonas aeruginosa outbreak in a Latin-American cancer centre and its associated risk factors. Braz. J. Infect. Dis., v.13, n.2, p.99103, 2009.

COSTA, G.F.M.; TOGNIM, M.C.B.; CARDOSO, C.L.; CARRARA-MARRONE, F.E.; GARCIA, L.B. Preliminary evaluation of adherence on abiotic and cellular surfaces of Acinetobacter baumannii strains isolated from catheter tips. Braz. J. Infect. Dis., v.10, n.6, p.346-351, 2006.

CORNAGLIA, G.; GIAMARELLOU, H.; ROSSOLINI, G.M. Metallo- $\beta$-lactamases: a last frontier for $\beta$-lactams? Lancet Infect. Dis., v.11, n.5, p.381-393, 2011.

FERREIRA, A.E.; MARCHETTI, D.P.; CUNHA, G.R.; OLIVEIRA, L.M.; FUENTEFRIA, D.B.; DALL BELLO, A.G.; BARTH, A.L.; CORÇÃO, G. Molecular characterization of clinical multiresistat isolates of Acinetobacter sp. From hospitals in Porto Alegre, State of Rio Grande do Sul, Brazil. Rev. Soc. Bras. Med. Trop., v.44, n.6, p.725-730, 2011.

GALES, A.C.; CASTANHEIRA, M.; JONES, R.N.; SADER, H.S. Antimicrobial resistance among Gram-negative bacilli isolated from Latin America: results from SENTRY antimicrobial surveillance program (Latin America, 20082010). Diagn. Microbiol. Infect. Dis., v.3, n.4, p.354-360, 2012.

GIAMARELLOU, H. Multidrug-resistant Gram-negative bacteria: how to treat and for how long. Int. J. Antimicrob. Agents, v.36, suppl 1, p.S50-S54, 2010.

GONÇALVES, D.C.P.S.; LIMA, A.B.M.; LEÃO, L.S.N.O.; CARMO FILHO, J.R.; PIMENTA, F.C.; VIEIRA, J.D.G. Detecção de metalo-beta-lactamase em Pseudomonas aeruginosa isoladas de pacientes hospitalizados em Goiânia, Estado de Goiás. Rev. Soc. Bras. Med. Trop., v.42, n.4, p.411-414, 2009. 
HOSOGLU, S.; HASCUHADAR, M.; YASAR, E.; USLU, S.; ALDUDAK, B. Control of an Acinetobacter baumannii outbreak in a neonatal ICU without suspension of service: a devastating outbreak in Diyarbakir, Turkey. Infection. Publicação on line, DOI 10.1007/s15010-011-0180-y, 2011.

KIDD, T.J.; GRIMWOOD, K.; RAMSAY, K.A.; RAINEY, P.B.; BELL, S.C. Comparison of three molecular techniques for typing Pseudomonas aeruginosa isolates in sputum samples from patients with cystic fibrosis. J. Clin. Microbiol., v.49, n.1, p.263-268, 2011 .

KUNZ, A.N.; BROOK, I. Emerging Resistant GramNegative Aerobic Bacilli in Hospital-Acquired Infections. Chemotherapy, v.56, n.6, p.492-500, 2010.

MAGIORAKOS, A.P.; SRINIVASAN, A.; CAREY, R.B.; CARMELI, Y.; FALAGAS, M.E.; GISKE, C.G.; HARBARTH, S.; HINDLER, J.F.; KAHLMETER, G.; OLSSON-LILJEQUIST, B.; PATERSON, D.L.; RICE, L.B.; STELLING, J.; STRUELENS, M.J.; VATOPOULOS, A.; WEBER, J.T.; MONNET, D.L. Multidrug-resistant, extensively drug-resistant and pandrug-resistant bacteria: an international expert proposal for interim standard definitions for acquired resistance. Clin. Microbiol. Infect., v.18, n.3, p.268-281, 2012.

MOSTACHIO, A.K.; HEIDJEN, I.; ROSSI, F.; LEVIN, A.S.; COSTA, S.F. Multiplex PCR for rapid detection of genes encoding oxacillinases and metallo- $\beta$-lactamases in carbapenem-resistant Acinetobacter spp. J. Med. Microbiol., v.58, n.11, p.1522-1524, 2009.

MOSTACHIO, A.K.; LEVIN, A.S.; RIZEK, C.; ROSSI, F.; ZERBINI, J.; COSTA, S.F. High prevalence of OXA-143 and alteration of outer membrane proteins in carbapenemresistant Acinetobacter spp. isolates in Brazil. Int. J. Antimicrob. Agents, v.39, n.5, p.396-401, 2012.

POIREL, L.; NAAS, T.; NORDMANN, P. Diversity, Epidemiology, and genetics of class D $\beta$-lactamases. Antimicrob. Agents Chemother., v.54, n.1, p.24-38, 2010.

PRESTERL, E.; NADRCHAL, R.; MAKRISTATHIS, A.; KOLLER, W.; ROTTER, M.L.; HIRSCHL, A.M. Molecular typing of Acinetobacter baumannii from ten different intensive care units of a university hospital. Eur. J. Clin. Microbiol. Infect. Dis., v.16, n.10, p.740-743, 1997.
PRATES, C.G.; MARTINS, A.F.; SUPERTI, S.V.; LOPES, F.S.; RAMOS, F.; CANTARELLI, V.V.; ZAVASCKI, A.P. Risk factors for 30-day mortality in patients with carbapenemresistant Acinetobacter baumannii during an outbreak in an intensive care unit. Epidemiol. Infect., v.139, n.3, p.411-418, 2011.

ROCHA, L.A.; VILELA, C.A.P.; CEZÁRIO, R.C.; ALMEIDA, A.B.; GONTIJO-FILHO, P. Ventilator-associated pneumonia in an adult clinical-surgical intensive care unit of a Brazilian university hospital: incidence, risk factors, etiology, and antibiotic resistance. Braz. J. Infect. Dis., v.12, n.1, p.80-85, 2008.

ROSSI, F. The challenges of antimicrobial resistance in Brazil. Clin. Infect. Dis., v.52, n.9, p.1138-1143, 2011.

SAALFELD, S.M.; VIANA, G.F.; SIQUEIRA, V.L.D.; CARDOSO, C.L.; GARCIA, L.B.; TOGNIM, M.C.B. Endemic carbapenem-resistant Acinetobacter baumannii in a Brazilian intensive care unit. J. Hosp. Infect., v.72, n.4, p.365-368, 2009.

SCOTT, F.W., PITT, T. Identification and characterization of transmissible Pseudomonas aeruginosa strains in cystic fibrosis patients in England and Wales. J. Med. Microbiol., v.53, n.7, p.609-615, 2004.

SNEATH, P.H.A., SOKAL, R.R. Numerical taxonomy: the principles and practice of numerical classification. San Francisco: Freeman, 1973. 573 p.

STEHLING, E.G.; LEITE, D.S.; SILVEIRA, W.D. Molecular typing and biological characteristics of Pseudomonas aeruginosa isolated from cystic fibrosis patients in Brazil. Braz. J. Infect. Dis., v.14, n.5, p.462-467, 2010.

SYRMIS, M.W.; O'CARROLL, M.R.; SLOOTS, T.P.; COULTER, C.; WAINWRIGHT, C.E.; BELL, S.C.; NISSEN, M. Rapid genotyping of Pseudomonas aeruginosa isolates harboured by adult and paediatric patients with cystic fibrosis using repetitive-element-based PCR assay. J. Med. Microbiol., v.53, n.11, p.1089-1096, 2004.

SWANENBURG, M.; URLINGS, H.A.P.; KEUZENKAMP, D.A.; SNIJDERS, J.M.A. Validation of ERIC PCR as a tool in epidemiologic research of Salmonella in slaughter pigs. J. Ind. Microbiol. Biotechnol., v.21, p.141-144, 1998. 
SZCUKA, E.; KAZNOWSKI, A. Typing of clinical and environmental Aeromonas sp. strains by random amplified polymorphic DNA PCR, repetitive extragenic palindromic $\mathrm{PCR}$, and enterobacterial repetitive intergenic consensus sequence PCR. J. Clin. Microbiol., v.42, n.1, p.220-228, 2004.

TOWNER, K.J. Acinetobacter: an old friend, but a new enemy. J. Hosp. Infect., v.73, p.355-363, 2009.

VIANA, G.F.; DOS SANTOS SAAFELD, S.M.; GARCIA, L.B.; CARDOSO, C.L.; PELISSON, M.; TOGNIM, M.C. Evolution of antimicrobial resistance of Acinetobacter baumannii in a university hospital. Lett. Appl. Microbiol., v.53, n.3, p.374-378, 2011.
ZAVASCKI, A.P.; CRUZ, R.P.; GOLDANI, L.Z. High Rate of Antimicrobial resistance in Pseudomonas aeruginosa at a tertiary-care teaching hospital in southern Brazil. Infect. Control Hosp. Epidemiol., v.25, n.10, p.805-807, 2004.

WIRTH, F.W.; PICOLI, S.U.; CANTARELLI, V.V.; GONÇALVES, A.L.S.; BRUST, F.R.; SANTOS, L.M.O.; BARRETO, M.F. Metallo- $\beta$-lactamase-producing Pseudomonas aeruginosa in two hospitals from Southern Brazil. Braz. J. Infect. Dis., v.13, n.3, p.170-172, 2009.

Received for publication on $09^{\text {th }}$ April 2012 Accepted for publication on $02^{\text {nd }}$ November 2012 